\title{
TOXICOLOGICAL IMPACT OF VOLATILE OILS EXTRACTED FROM FOUR PLANTS AND THEIR JOINT ACTION WITH PHOSPHINE ON THE BROAD BEAN BEETLE BRUCHIDIUS INCARNATUS (BOH.) Barakat, Ahmed.ı, Makram Sayed ${ }^{2}$, Ahmed Etman', Ibrahim Ali². \\ ${ }^{1}$ Elhelb Pesticides and Chemicals Company. \\ 2 Plant Protection Dept. Faculty of Agric.Fayoum University.
}

\section{ABSTRACT}

This study was carried out to determine the toxicity of four volatile oils of Wild mint (Mentha longifolia L.), Marjoram (Origanum majorana L.), Lemon peel (Citrus aurantiifolia Christm.), Orange peel (Citrus sinensis L.) and phospheine, against the adult of the Broad Bean Beetle Bruchidius incarnatus (Boh) (coleopteran: Bruchidae). The phosphine and marjoram oil were the most effective against $B$. incarnatus adults, $24 \mathrm{~h}$ post treatment. Their $\mathrm{LC}_{50}$ 's were 0.0884 and $40.266 \mathrm{mg} / \mathrm{l}$, resspectivley. In addition, the binary mixtures of wild mint with Marjoram volatile oils at all ratios 1:1, 1:2 and 2:1 exhibit potentiation effect. On the other hand, the binary mixtures of Lemon with Orange or Marjoram, showed antagonistic effect. The mixture of Wild mint with Lemon showed potentiation effect at the ratio of 2:1 and the same effect was recorded at the ratio of 1:1 in the mixture of Wild mint with Orange. The mixture of Wild mint with Lemon and Wiled mint /Orange showed antagonistic effect at the ratios of 1:1 and 1:2, respectively. But the mixture of Wild mint with Orange gave an additive effect at the ratio of $2: 1$, against adult of $B$. incarnatus, $24 \mathrm{~h}$ post treatment. Concerning the binary mixtures of phosphine and the four volatile oils gave potentiation effect.

Keywords: Bruchidius incarnates, volatile oils, joint action.

\section{INTRODUCTION}

Legumes is the most economic important crop in Egypt and the world. It is one of the most important human and animal food in different countries in the world.(Metwally,1990)

Away from pesticides and their side effects the world is seeking for a new way to reduce their adverse effect through looking up for alternative solutions, such as essential oils, because of its effective as insecticidal, antifeedant, repellent, oviposition deterrent, growth regulatory and antivector activities (Saad, 2013)

There is ongoing research on herbs and medicinal plants for to be used as fumigants against various stored grain insects and house fly. A correlation between the structure of a monoterpene and its toxicity in the house fly, indecated that monoterpene ketone was more toxic than monoterpene alcohol. Results of oxygenated monoterpenes such as 1,8-cineole, menthone, eugenol, linalool, isosafrol and terpinen-4-ol, show that they were toxic to $S$. oryzae. Also, they reported that mono- and bicyclic monoterpenes are more toxic than acylic monoterpenes except to linalool. However, Result show that thyme essential oil showed potent fumigant toxicity against $L$. mali and its primary monoterpenes $\alpha$ pinene was most active constituent for the fumigant toxicity against the insects.

Fayoum J. Agric. Res. \& Dev., Vol. 34, No.1, January, 2020 
Choi, et al., (2006). The efficacy of some volatile oils attract the attention of the biological and toxicological scientists to use it in the pest control (Lee, et al., 2004)

The objectives of this study were to determine the toxicological impact of the phosphine, volatile oils isolated from Wild mint (M. longifolia), Marjoram ( $O$. majorana), Lemon peel (C. aurantiifolia) and Orange peel (C. sinensis) and their binary mixture against broad been beetle $B$. incarnates (Boh).

\section{MATERIALS NAD METHODS}

\section{Insect culture and rearing conditions}

One kilogram of faba bean seeds were sterilized by heating up to $70-80^{\circ} \mathrm{C}$ for five hours in an oven to destroy any present infection (Metwally, 1990). $1 \mathrm{Kg}$ Plastic jars were used in mass rearing of the test insect. Each jar was half fillet with sterilized beans and a group of adult insects were added. A circular piece in the middle of the plastic cover of jar was cut and replaced with muslin cloth for air supplying. The jars were incubated (Gallenkamp) at $28 \pm 2^{\circ} \mathrm{C}$.

Each emerged adults were trnsfered to a clean jars and treated with the same condition as mentioned above.

\section{Extraction of volatile oils.}

Steam distillation occurred using a Clevenger-type apparatus according to the method of Khani and Asghari (2012). Volatile oils were extracted from the Crushed aerial parts of the Wild mint and Marjoram, and crushed frozen peels of Lemon and Orange. Fifty gram of the plant was mixed with water at the ratio of 1:10 in a round bottom flask of the Clevenger apparatus and left to boil for a four hour to oil distillation. The oil was dehydrated with anhydrous sodium sulfate and immediately stored in airtight glass tube, and kept in a refrigerator at $4{ }^{\circ} \mathrm{C}$ until used for biological activity tests.

\section{Fumigation treatment.}

\section{Volatile oil treatment.}

A stock solution of each volatile oil was prepared by weigting $0.5 \mathrm{~g}$ of oil in a vial and completed to $10 \mathrm{ml}$ by acetone, to get a stock solution. Different concentrations from each volatile oil were prepared and the fumigation effect of volatile oils has been carried out in $125 \mathrm{ml}$ cups with sliding doors. Four replicates, were made from each treatment and contain 25 adults ca. two days old of $B$. incarnatus (Boh.). Each cup was covered by a piece of plastic cover $(8 \mathrm{~cm}$ diameter), and a treated filter paper $(5 \mathrm{~cm}$ diameter) with one $\mathrm{ml}$ of volatile oil concentration under investigation, and the cup cover closed. These steps were repeated in all treatments and also untreated control.

\section{Phosphine $\left(\mathrm{PH}_{3}\right)$ treatment.}

Fumigation effect of phosphine has been conducted in $125 \mathrm{ml}$ bottles with rubber stopper. This was set by adding one pill of phosphine $57 \%$ in $500 \mathrm{ml}$ bottle, then $100 \mu \mathrm{l}$ of water was added on the center of the pill and closed tightly by a stopper. The bottle was left for one hour to generate the phosphine gas. Different

Fayoum J. Agric. Res. \& Dev., Vol. 34, No.1, January, 2020 
TOXICOLOGICAL IMPACT OF VOLATILE 3

volumes of phosphine were taken by $1 \mathrm{ml}$ syringe and injected in the treatment botteles. On the other hand, the pure air took place $\mathrm{pH}_{3}$ in the control. The experiment was carried out under the same rearing conditions and the mortalities were recorded 24 hours post treatment.

\section{Joint action.}

The calculated values of $\mathrm{LC}_{25}$ of the volatile oils and phosphine, were used to test the joint action of binary mixtures. A binary mixture between volatile oils and phosphine at the rotes 1:1, 1:2 and 2:1 were applied by fumigation technique against $B$. incarnates adults. The percent of mortality rate was recorded $24 \mathrm{~h}$ post treatment and the co-toxicity factor was estimated using equation represented by Mansour, et al., (2010).

\section{RESULTS AND DISCUSSION}

\section{The effect of the volatile oils.}

The four volatile oils under investigation can be arranged according to their toxic effect against $B$. incarnatus adults, in descending order as follows: Marjorma, Wild mint, Lemon and Orange. Their values LC $_{\mathbf{5 0}}$ 's were 40.266, 40.465, 117.357 and $243.023 \mathrm{mg} / \mathrm{l}$, respectively (table 1 and fig.2). The values $\mathrm{LC}_{\mathbf{9 0}}$ level, Marjorma was more effective than Wild mint where Orange was more effective than Lemon.

In this respect Sabbour (2013) showed that Jatropha curcas oils were given the higher mortality against $B$. incarnates when treated at the corresponding concentrations. Accumulative mortality (\%) of Ephestia elutella and B. incarnates larvae increased gradually by increasing the period of exposure of treated foam with different tested oils. After seven days of treatment, the Jojoba Seed oil, Jatropha curcas and Canola oil the accumulative mortality B. incarnates recorded $71.5,73.4$ and 40.1, respectively as compared to 33.1 in the control. Khiralla (2007) reported that $B$. incarnatus was quite sensitive to the fumigant action of garlic oil; as indicated by their low value $\operatorname{LD}_{50}(1343.51 \%$ for $B$. incarnatus $)$. Slope was more or less similar in value, 0.26 for $B$. incarnates.

Table.1. The fumigation effect of volatile oils and (phosphine) against $B$. incarnatus (Boh.).

\begin{tabular}{|c|c|c|c|c|c|c|c|c|c|}
\hline \multirow{2}{*}{$\begin{array}{c}\text { Test } \\
\text { material }\end{array}$} & \multirow{2}{*}{$\begin{array}{l}\mathrm{LC}_{50} \\
\mathrm{mg} / \mathrm{l}\end{array}$} & \multicolumn{2}{|c|}{ Confidence level } & \multirow{2}{*}{$\begin{array}{l}\mathrm{LC}_{90} \\
\mathrm{mg} / \mathrm{l}\end{array}$} & \multicolumn{2}{|c|}{$\begin{array}{c}\text { Confidence } \\
\text { level }\end{array}$} & \multirow{2}{*}{ Slope } & \multirow{2}{*}{$\begin{array}{c}\text { Toxicity } \\
\text { Index(\%) }\end{array}$} & \multirow{2}{*}{$\begin{array}{l}\text { Relative } \\
\text { potency }\end{array}$} \\
\hline & & lower & upper & & lower & upper & & & \\
\hline Wild mint & 40.47 & 4408.02 & 5672.49 & 79.88 & 8702.48 & 12090.9 & $4.3 \leq \pm \cdot .01$ & 457.748 & 40.47 \\
\hline Marjorma & 40.27 & 4656.7 & 5376.6 & 62.27 & 7155.2 & 8760.1 & $6.7 \vee_{ \pm} \cdot . \vee V$ & 455.497 & 40.27 \\
\hline Lemon & 117.4 & 28204 & 32393.22 & 369.5 & 41938.7 & 53951.7 & $7.04 \pm \cdot . \wedge 7$ & 2749.128 & 1 \\
\hline Orange & 243.02 & 12470.2 & 17217.6 & 320.4 & 32163.7 & 54152.5 & $2.9 \leq \pm \cdot . r$. & 1327.567 & 117.4 \\
\hline $\begin{array}{c}\text { Phosphine } \\
\text { (ph3) }\end{array}$ & 0.0884 & 9.541 & 12.521 & $\begin{array}{c}\mu \mathrm{l} / 1 \\
0.232 \\
8\end{array}$ & 25.297 & 34.691 & $3.0^{\circ} \pm \cdot r \tau$ & 100 & 0.0884 \\
\hline
\end{tabular}

Fayoum J. Agric. Res. \& Dev., Vol. 34, No.1, January, 2020 


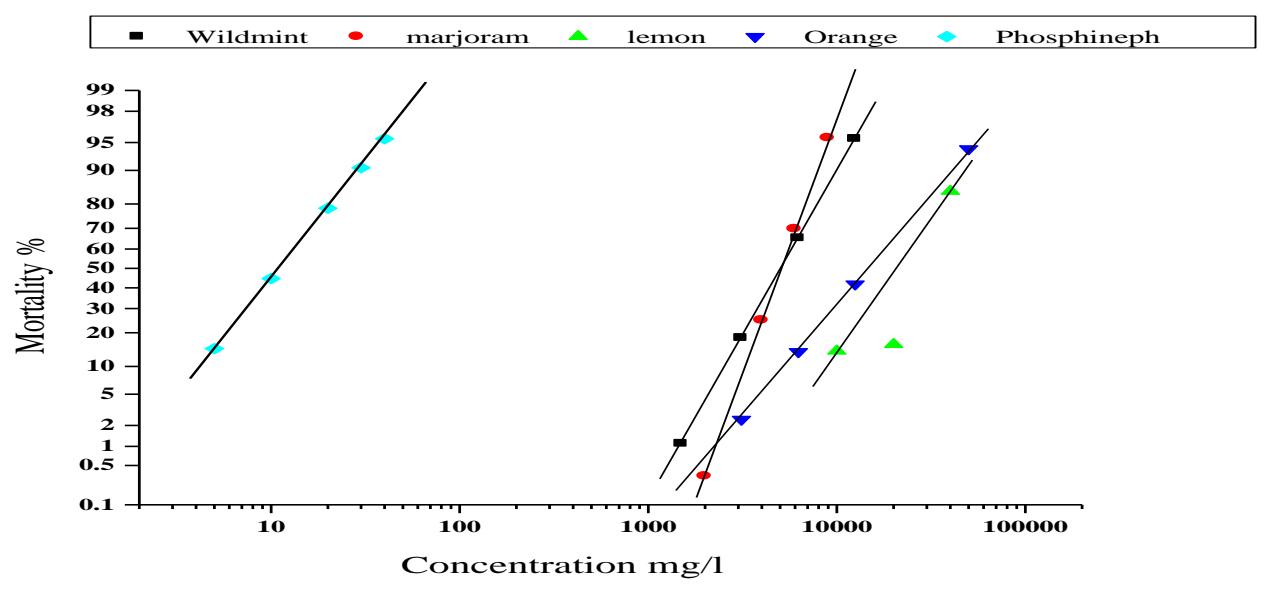

Fig.2. The toxicity lines and $\mathrm{LC}_{50}$ values of volatile oils $M$. longifolia, O. majorana, $C$.

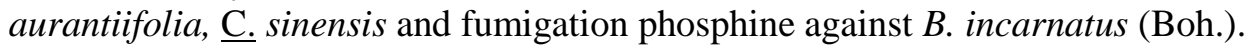

\section{Toxicological effect of binary Mixtures of tested volatile oils and fumigation phosphine against $B$. incarnatus (Boh.}

The mixtures of Wild mint and Marjoram showed potentiation when used at ratios of 1:1, 1:2, 2:1. The mixtures of Wild mint and Lemon exhibited potentiation in just one ratio 2:1. The mixtures of Wild mint and Orange induced potentiation in one ratio 1:1. On the other hand, the binary Mixtures of all test material against $B$. incarnatus (Boh.) demonstrated an additive effect when used at ratio 2:1 with the mixture of Wild mint and Orange. The mixture of Lemon and Marjoram, Orange and Marjoram and Lemon and Orange showed an antagonism effect at all mixing ratios. Also the mixture of Wild mint and Lemon, Wild mint and Orange at the ratios 1:1 and 1:2 showed an antagonism effect, respectively (Table 2 Fig 3).

The effect of the binary mixtures of the insecticide under investigation and naturally occurring substances were calculated $24 \mathrm{~h}$ post treatment. The mixture of Phosphine and Wild mint, Phosphine and Marjoram showed potentiation when used at ratios 1:1 and exhibited additive when used at ratios 1:2 and 2:1.On the other hand, Phosphine and Lemon, Phosphine and Orange induced potentiation effect of when used at all ratios, where the mixture of Phosphine and Orange exhibited additive when used at ratio 1:2 (Table 2 Fig 3).

Fayoum J. Agric. Res. \& Dev., Vol. 34, No.1, January, 2020 
TOXICOLOGICAL IMPACT OF VOLATILE .................................5

Table.2. The Binary Mixtures of four volatile oils and Phosphen against $B$. incarnatus (Boh.)

\begin{tabular}{|c|c|c|c|c|c|}
\hline Combinations & Mixing ratio & $\begin{array}{c}\text { Expected } \\
\text { mortality } \\
\%\end{array}$ & $\begin{array}{c}\text { Observed } \\
\text { mortality } \\
\%\end{array}$ & $\begin{array}{c}\text { Co- } \\
\text { toxicity } \\
\text { factor } \\
\end{array}$ & $\begin{array}{c}\text { Joint action } \\
\text { category }\end{array}$ \\
\hline \multirow{3}{*}{$\begin{array}{l}\text { Wild mint + } \\
\text { Marjoram }\end{array}$} & $1: 1$ & 50 & 100 & 100 & Potentiation \\
\hline & $1: 2$ & 75 & 97 & 29 & Potentiation \\
\hline & $2: 1$ & 75 & 100 & 33 & Potentiation \\
\hline \multirow{3}{*}{ Wild mint + Lemon } & $1: 1$ & 50 & 31 & -38 & Antagonism \\
\hline & $1: 2$ & 75 & 49 & -34 & Antagonism \\
\hline & $2: 1$ & 75 & 95 & 26 & Potentiation \\
\hline \multirow{3}{*}{ Wild mint + Orange } & $1: 1$ & 50 & 80 & 60 & Potentiation \\
\hline & $1: 2$ & 75 & 32 & -57 & Antagonism \\
\hline & $2: 1$ & 75 & 87 & 16 & Additive \\
\hline \multirow{3}{*}{ Lemon + Orange } & $1: 1$ & 50 & 22 & -56 & Antagonism \\
\hline & $1: 2$ & 75 & 18 & -76 & Antagonism \\
\hline & $2: 1$ & 75 & 12 & -84 & Antagonism \\
\hline \multirow{3}{*}{ Orange + Marjoram } & $1: 1$ & 50 & 26 & -48 & Antagonism \\
\hline & $1: 2$ & 75 & 29 & -61 & Antagonism \\
\hline & $2: 1$ & 75 & 20 & -73 & Antagonism \\
\hline \multirow{3}{*}{ Lemon+ Marjoram } & $1: 1$ & 50 & 30 & -40 & Antagonism \\
\hline & $1: 2$ & 75 & 39 & -48 & Antagonism \\
\hline & $2: 1$ & 75 & 19 & -74 & Antagonism \\
\hline \multirow{3}{*}{$\mathrm{PH}_{3}+$ Wild mint } & $1: 1$ & 50 & 92 & 84 & Potentiation \\
\hline & $1: 2$ & 75 & 87 & 16 & Additive \\
\hline & $2: 1$ & 75 & 85 & 13 & Additive \\
\hline \multirow{3}{*}{$\mathrm{PH}_{3}+$ Marjoram } & $1: 1$ & 50 & 87 & 74 & Potentiation \\
\hline & $1: 2$ & 75 & 89 & 19 & Additive \\
\hline & $2: 1$ & 75 & 86 & 15 & Additive \\
\hline \multirow{3}{*}{$\mathrm{PH}_{3}+$ Lemon } & $1: 1$ & 50 & 91 & 82 & Potentiation \\
\hline & $1: 2$ & 75 & 99 & 32 & Potentiation \\
\hline & $2: 1$ & 75 & 96 & 28 & Potentiation \\
\hline \multirow{3}{*}{$\mathrm{PH}_{3}+$ Orange } & $1: 1$ & 50 & 78 & 56 & Potentiation \\
\hline & $1: 2$ & 75 & 92 & 13 & Additive \\
\hline & $2: 1$ & 75 & 85 & 23 & Potentiation \\
\hline
\end{tabular}

Fayoum J. Agric. Res. \& Dev., Vol. 34, No.1, January, 2020 


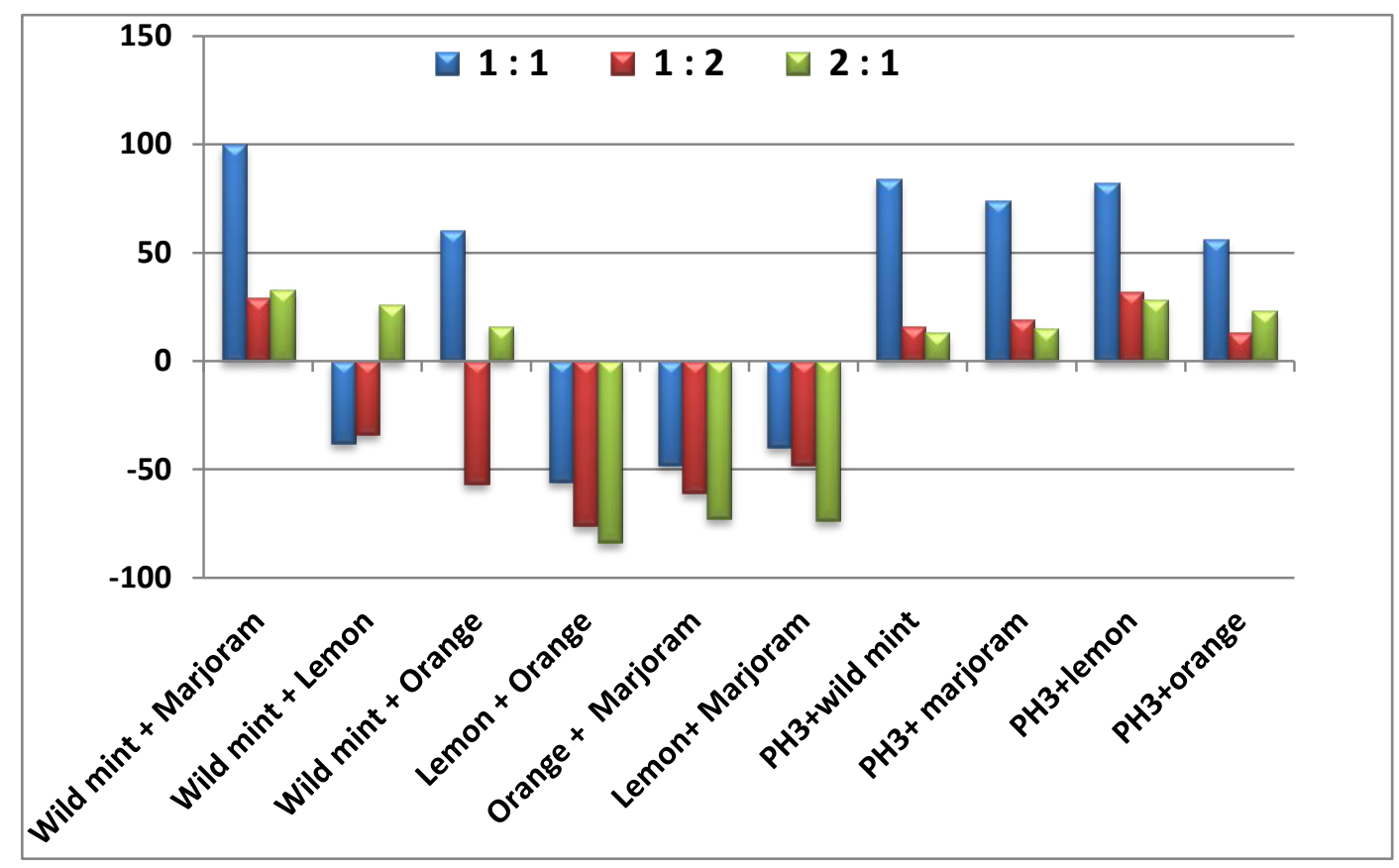

Fig.3. The binary mixtures of four volatile oils and fumigation Phoshine against $B$. incarnatus (Boh.)

\section{REFERENCES}

Choi, w.; B. Parkb.; Y. Lee.; D. Y. Janga.;H. Y. Yoond and S. Lee (2006): Fumigant toxicities of essential oils and monoterpenes against Lycoriella mali adults. J. Crop. Prot., 25: 398-401.

Khani, A. and J. Asghari. (2012): Insecticide activity of essential oils of Mentha longifolia, Pulicaria gnaphalodes and Achillea wilhelmsii against two stored product pests, the flour beetle, Tribolium castaneum, and the cowpea weevil, Callosobruchus maculatus. J. Ins. Sci., 12(73): 1-10.

Khiralla, M. M. (2007): The fumigant action of chinese Garlic cultivar volatile oils against Callosobruchus maculatus (F.) and Bruchidius incarnatus (Boh.), (Coleoptera: Bruchidae)., M.Sc.Thesis.Sudan University of Sci. and Tech.46-72.

Lee, B.; P. C. Annis.; F. Tumaalii and W. Choi (2004): Fumigant toxicityof essential oils from the Myrtaceae family and 1,8-cineole against 3 major stored-grain insects. J. Sto. Pro. Res., 40: 553-564.

Fayoum J. Agric. Res. \& Dev., Vol. 34, No.1, January, 2020 
TOXICOLOGICAL IMPACT OF VOLATILE 7

Mansour, Sameh A.; Reda F.A. Baker.; Laila S. A. Hamouda and Reham I. Mohamed. (2010): Toxic and Synergistic Properties of Several Botanical Extracts against Larval and Adult Stages of the Mosquito, Anopheles pharoensis. Bio pestic. Int. 6: 129-145.

Metwally, M. M. (1990): Bionomics of Bruchidius Incarnatus BOH. In Egypt., Kluwer Academic Publishers.; 25-36.

Saad, M. M. G. (2013): Chemical Composition and Biological Activities of Four Citrus Essential Oils.J. Plant prot. And Path., Mansoura Univ., Vol. 4 (9): 767-780.

Sabbour, M. M. (2013): Evaluations of some extracted natural oils against Bruchidius incarnates and Ephestia elutella. GJSR J., 1(1): 1-7.

الأثرالسام للزيوت الطيارة المستخلصة من أربع نباتات وأرتباطها مع مركب الفوسفين على خنفساء الفول

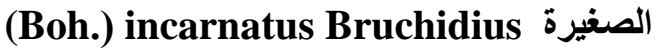

أحمد نبيل بركات1، مكرم محمد احمد سيد، أحمد عزمى عتمان2، إبراهيم حامد على. 1 اشركه الهلب للمبيدات و الكيماويات. 2 قسم وقايه النبات - كليه الزر اعهات - جامعه الفيوم.

أجريت هذه الدر اسه للتعرف على سميه أربعه من الزيوت العطريه و هى النعناع البرى، البردقوش،

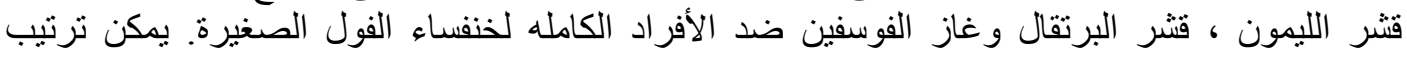

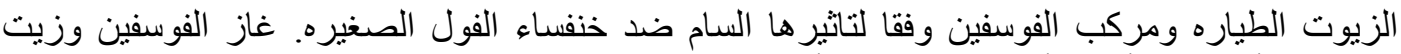

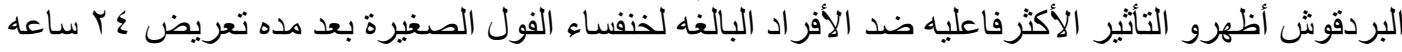

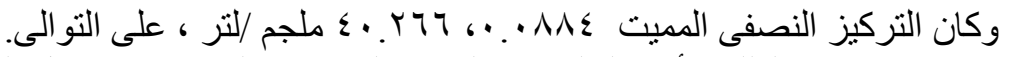

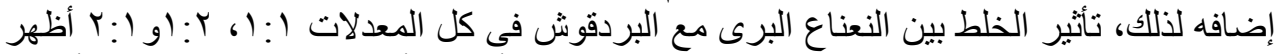

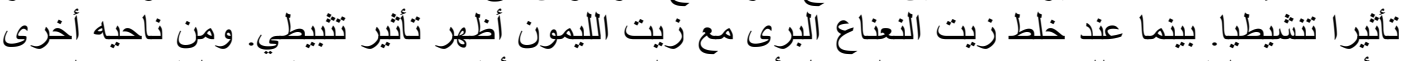

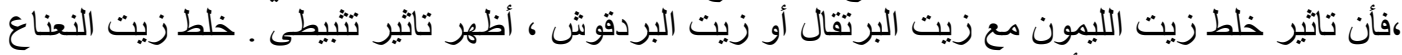

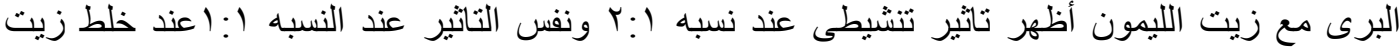

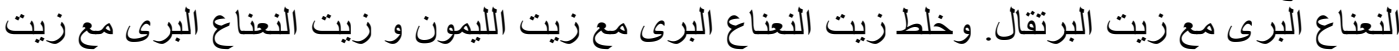

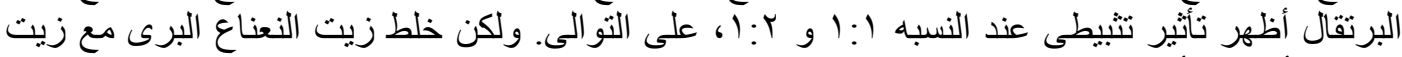

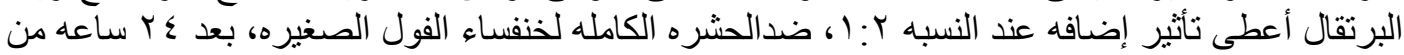

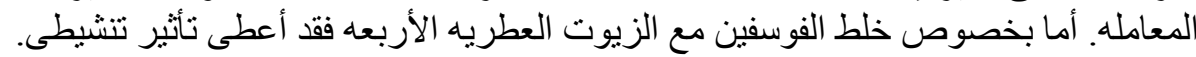

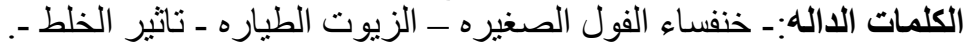

Fayoum J. Agric. Res. \& Dev., Vol. 34, No.1, January, 2020 